\title{
PENGARUH SOCIAL SUPPORT TERHADAP ORGANIZATIONAL CITIZENSHIP BEHAVIOR PADA KARYAWAN WANITA DI PT INKA DENGAN WORK FAMILY ENRICHMENT SEBAGAI VARIABEL MEDIASI
}

\author{
Arithea Ayu Amritha W. \& Ahmad Rizki Sridadi \\ Fakultas Ekonomi dan Bisnis Universitas Airlangga Surabaya \\ e-mail: ayuamritha@gmail.com
}

\begin{abstract}
This research was conducted to examine the effect of Social Support on Organizational Citizenship Behavior on Female Employees at PT Inka with Work Family Enrichment as a mediating variable. The sample used was 62 female employees. The research method used is quantitative to determine the relationship between variables. Exogenous variables, social support, intervening variables are work family enrichment, endogenous variables are $O C B$. The results of this study are significantly positive effect on Social Support on Organizational Citizenship Behavior with Work Family Enrichment as a mediating variable.
\end{abstract}

Keywords: social support, organizational citizenship behavior, work family enrichment

\section{PENDAHULUAN}

Dalam masyarakat modern, wanita semakin diharapkan memiliki karier dan mempunyai penghasilan tetap untuk menghidupi keluarganya (Werner, 2016). Berdasarkan Badan Pusat Statistik (BPS) tercatat pada tahun 2018 sebanyak $38,20 \%$ merupakan pekerja wanita di Indonesia. Seorang profesional wanita yang sudah menikah akan menjalankan peran ganda antara pekerjaan dan sebagai ibu rumah tangga (Eddleston dan Powell, 2012).

Karyawan wanita yang melanjutkan pekerjaan setelah menikah memiliki tanggung jawab yang lebih besar daripada pria dikarenakan harus datang tepat waktu untuk menjaga anak, memasak, dan mengurus keluarga sehingga memiliki tuntutan yang lebih tinggi untuk memenuhi kebutuhan tersebut (Shiva, 2013). Di sisi lain, wanita juga dituntut dengan target kinerja dan komitmen pada perusahaan (Julka dan Mathur, 2017). Pada beberapa literatur, untuk mening- katkan kualitas hidup individu dalam memenuhi tuntutan peran sebagai anggota keluarga dapat ditingkatkan oleh pengalaman individu menjalankan peran pekerjaan mereka dengan mentransfer pengetahuan, keterampilan, sumber daya material, dan social capital yang diperoleh saat menjalankan peran sebagai karyawan (Zhang et al., 2018). Tingkat sejauh mana pengalaman dalam satu peran sebagai karyawan dapat meningkatkan kualitas hidup pada peran sebagai anggota keluarga dikenal sebagai work family enrichment (Greenhaus dan Powell, 2006).

Baral dan Bhargava (2009) menemukan bahwa peningkatan kualitas diri karyawan dalam menjalankan peran sebagai anggota keluarga (work family enrichment) dapat meningkatkan organizational citizenship behavior (OCB). Hasil penelitian Bragger et al. (2005) menemukan bahwa karyawan yang merasa tidak mampu memenuhi tanggung jawabnya sebagai anggota keluarga karena tuntutan pekerjaan dan memiliki 
tingkat OCB yang rendah. OCB didefinisikan oleh Smith et al. (1983) sebagai tindakan sukarela yang dilakukan karyawan tanpa paksaan dan tidak secara formal berada dalam job description.

Pentingnya work family enrichment dalam meningkatkan OCB dan pentingnya OCB dalam peningkatan performa organisasi mendorong penelitian ini untuk meneliti faktor yang dapat meningkatkan work family enrichment. Greenhouse dan Powell (2006) menjelaskan bahwa salah satu sumber daya yang dapat ditransfer dari salah satu domain (pekerjaan) kepada domain lain (keluarga) adalah social capital. Social support merupakan salah satu bagian dari social capital yang dapat ditransfer dari domain kerja ke dalam domain keluarga karyawan. Social support yang menjadi social capital dalam dunia kerja berasal dari organisasi, supervisor langsung, dan rekan kerja (Tang et al., 2012).

Dengan demikian, penelitian ini ingin menguji pengaruh social support yang terdiri dari organizational support, supervisor support, dan coworker support pada work family enrichment sehingga dapat meningkatkan OCB yang dilakukan karyawan. Selain itu, juga peran work family enrichment dalam memediasi hubungan antara supervisor support dengan OCB.

Penelitian ini akan dilakukan pada salah satu perusahaan BUMN, yaitu PT Industri Kereta Api (PT Inka). PT Inka merupakan industri yang bergerak di bidang pembuatan kereta api baru dan juga reparasi kereta api. Terdapat 202 karyawan perempuan dari total karyawan 1711 orang. Berdasarkan survei awal, 11 dari 21 karyawan wanita PT Inka merasa memiliki suasana hati yang kurang baik setelah melakukan pekerjaan di kantor sehingga mereka tidak dapat menjalankan peran sebagai anggota keluarga dengan baik.

\section{LANDASAN TEORI}

\section{Definisi Organizational Citizenship Behaviour (OCB)}

Organizational citizenship behaviour (OCB) didefinisikan sebagai perilaku individu di mana memiliki hak untuk memilih, yang secara tidak langsung dikaitkan dengan sistem imbalan serta memberikan kontribusi pada fungsi organisasi (Organ et al., 2006).

\section{Manfaat Organizational Citizenship Behavior dalam Perusahaan}

Melalui sejumlah riset, OCB diyakini dan terbukti dapat memberikan manfaat yang besar terhadap organisasi sebagai berikut (Podsakoff et al., 2000).

1. Organizational citizenship behavior meningkatkan produktivitas rekan kerja.

2. Organizational citizenship behavior meningkatkan produktivitas manajer.

3. Organizational citizenship behavior menghemat sumber daya yang dimiliki manajemen dan organisasi secara keseluruhan.

4. Organizational citizenship behavior membantu menghemat energi sumber daya yang langka untuk memelihara fungsi kelompok.

5. Organizational citizenship behavior dapat menjadi sarana efektif untuk mengoordinasi kegiatan-kegiatan kelompok kerja.

6. Organizational citizenship behavior meningkatkan kemampuan organisasi untuk menarik dan mempertahankan karyawan terbaik.

7. Organizational citizenship behavior meningkatkan stabilitas kerja organisasi.

8. Organizational citizenship behavior meningkatkan kemampuan organisasi untuk beradaptasi dengan perubahan lingkungan. 
Arithea Ayu Amritha W. \& Ahmad Rizki Sridadi, Pengaruh Social Support terhadap Organizational Citizenship Behavior pada Karyawan Wanita di PT Inka dengan Work Family Enrichment sebagai Variabel Mediasi

\section{Definisi Work-Family Enrichment (WFE)}

Greenhaus dan Powell (2006) sendiri mendefinisikan work-family enrichment, yaitu sejauh mana pengalaman dalam salah satu peran akan meningkatkan kualitas hidup dalam peran lain.

\section{Sumber Daya yang Dihasilkan Work-Family} Enrichment

Greenhaus dan Powell (2006) mengidentifikasi dan menetapkan lima jenis sumber daya yang dihasilkan oleh work-family enrichment.

1. Keterampilan dan perspektif (skills and perspectives)

2. Psikologis dan fisik (psychological and physical)

3. Modal sosial (social capital)

4. Fleksibilitas (flexibility)

5. Material bahan (material Resources)

\section{Definisi Perceived Organizational Support (POS)}

Perceived organizational support (POS) merupakan keyakinan karyawan mengenai sejauh mana organisasi menghargai kontribusi karyawan dan peduli terhadap kesejahteraan dirinya (Rhoades dan Eisenberger, 2002).

\section{Definisi Supervisor Support}

Nijman (2004) mendefinisikan supervisor support sebagai sejauh mana supervisor berperilaku dengan cara mengoptimalkan penggunaan pengetahuan, keterampilan, dan sikap karyawan yang diperoleh dalam pelatihan pada pekerjaan.

\section{Definisi Perceived Coworker Support}

Coworker support adalah sebagai salah satu bantuan emosional dan instrumental yang diterima melalui hubungan interpersonal di tempat kerja. Coworker support menggambarkan hubungan karyawan dengan teman kerja sehingga dapat menciptakan suasana yang mendukung pekerjaan (Hong \& Waheed, 2011).

\section{MODEL PENELITIAN}

Berdasarkan uraian hubungan antar-variabel dan hipotesis maka peneliti merumuskan model penelitian sebagai berikut.

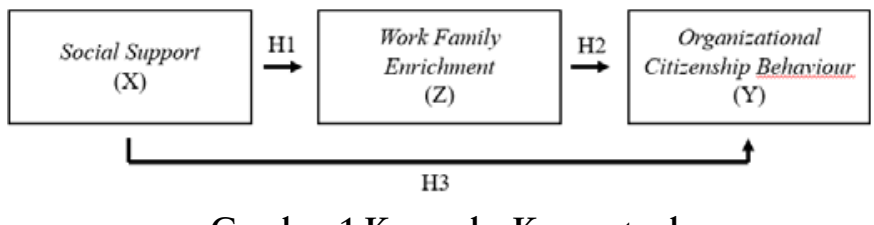

Gambar 1 Kerangka Konseptual

Keterangan:

$\mathrm{X}$ : Variabel social support (variabel eksogen/independen)

Y : Variabel organizational citizenship behaviour (variabel endogen/dependen)

$\mathrm{Z}$ : Variabel work family enrichment (variabel intervening)

\section{HIPOTESIS PENELITIAN}

Hipotesis penelitian ini adalah sebagai berikut.

H1: Social support berpengaruh positif signifikan terhadap work family enrichment

$\mathrm{H} 2$ : Work family enrichment berpengaruh positif signifikan terhadap OCB

H3: Work family enrichment dapat memediasi hubungan antara social support dengan OCB

\section{METODE PENELITIAN}

\section{Populasi dan Sampel}

Populasi merupakan semua objek atau fenomena yang akan diteliti yang mempunyai kualitas dan karakteristik tertentu yang ditetapkan oleh 
peneliti untuk dipelajari dan kemudian ditarik kesimpulannya (Sugiyono, 2012:115). Populasi dalam penelitian ini adalah karyawan wanita PT Inka. Adapun jumlah karyawan wanita yang bekerja di PT Inka adalah 202 dari 1711 karyawan.

Dalam penelitian ini, teknik pengambilan sampel yang digunakan adalah teknik pengambilan sampel non-probabilitas. Adapun kriteria dalam pemilihan sampel penelitian ini adalah (1) karyawan PT Inka yang memiliki masa kerja lebih dari satu tahun dan (2) telah menikah. Jumlah karyawan wanita yang telah menikah dan mempunyai anak adalah 62 .

\section{Teknik Pengumpulan Data}

Pengumpulan data dilakukan melalui survei pada responden dengan memberikan wawancara terstruktur dengan menggunakan kuesioner. Dalam kuesioner tersebut berisikan pernyataanpernyataan yang harus dijawab oleh responden dengan pilihan jawaban yang sudah ditentukan sebelumnya. Data yang dianalisis merupakan data yang dikumpulkan melalui survei kuesioner (data primer), dengan jenis data adalah data interval. Pilihan jawaban yang disediakan dalam kuesioner yang akan dibagikan kepada para responden adalah dengan menggunakan skala pengukuran ordinal, yakni skala likert. Tiap respons dihubungkan dengan nilai skor atau nilai skala untuk masing-masing pernyataan.

Sangat setuju diberikan

Setuju diberikan

Cukup diberikan

Tidak setuju diberikan

Sangat tidak setuju diberikan

\section{Analisis Data}

Partial least square (PLS) merupakan factor indeterminacy metode analisis yang powerful dikarenakan tidak berasumsi bahwa data harus dengan pengukuran skala tertentu dan dapat menggunakan jumlah sampel kecil (Ghozali, 2008). PLS selain dapat digunakan sebagai konfirmasi teori juga dapat digunakan untuk membangun hubungan yang belum ada landasan teorinya atau untuk pengujian proposisi (Ghozali, 2008).

\section{HASIL DAN PEMBAHASAN}

\section{Profil Responden}

Dari total 62 responden, jumlah masa kerja yang paling banyak adalah telah bekerja lebih dari 20 tahun, sebesar 31 responden (50\%), diikuti dengan karyawan yang telah bekerja antara 1-5 tahun sebanyak 14 responden (22,58\%) dan usia 16-20 tahun sebanyak 3 responden (4.84\%). Berdasarkan data tersebut, responden terbanyak adalah karyawan wanita dengan masa kerja lebih dari 20 tahun.

\section{Analisis Model Pengukuran}

Pada penelitian ini, peneliti melakukan analisis model pengukuran untuk mengetahui validitas dan reliabilitas model penelitian. Peneliti berharap dapat mengetahui seberapa baik item kuesioner mengukur sifat dan konsep variabel yang diukur dan mengetahui konsistensi item kuesioner dalam mengukur variabel yang sama dalam waktu dan tempat yang berbeda.

\section{Uji Validitas Model Pengukuran}

Pada penelitian ini, model pengukuran menghasilkan nilai outer loading factor yang sudah melalui estimasi yang terstandardisasi (standardized estimate) untuk mengukur validitas konvergen indikator penelitian. Berikut penyajian hasil uji validitas konvergen. 
Arithea Ayu Amritha W. \& Ahmad Rizki Sridadi, Pengaruh Social Support terhadap Organizational Citizenship Behavior pada Karyawan Wanita di PT Inka dengan Work Family Enrichment sebagai Variabel Mediasi

Pertanyaan variabel social support yang diajukan kepada responden mempunyai outer loading factor di atas 0,4. Menurut Ghozali (2006), indikator dikatakan valid jika memiliki outer loading factor lebih dari 0.4. Dengan demikian, dapat dikatakan bahwa masing-masing pertanyaan valid dan dapat digunakan untuk mengukur konstruk dalam penelitian.

Pertanyaan variabel work family enrichment yang diajukan kepada responden, mempunyai outer loading factor di atas 0,4 . Menurut Ghozali (2006), indikator dikatakan valid jika memiliki outer loading factor lebih dari 0.4. Dengan demikian, dapat dikatakan bahwa masing-masing pertanyaan valid dan dapat digunakan untuk mengukur konstruk dalam penelitian.

Pertanyaan variabel OCB yang diajukan kepada responden, mempunyai outer loading factor di atas 0,4. Menurut Ghozali (2006), indikator dikatakan valid jika memiliki outer loading factor lebih dari 0.4. Dengan demikian, dapat dikatakan bahwa masing-masing pertanyaan valid dan dapat digunakan untuk mengukur konstruk dalam penelitian.

Selain uji validitas konvergen terdapat uji validitas lainnya yakni validitas diskriminan. Uji validitas diskriminan digunakan untuk mengetahui apakah model pengukuran setiap blok indikator memiliki loading yang lebih tinggi untuk setiap variabel laten yang diukur dibandingkan dengan indikator untuk variabel laten lainnya. Indikator dikatakan valid jika korelasi kon-

Uji Validitas Diskriminan - Nilai RAVE dengan Korelasi antar Variabel

\begin{tabular}{|c|c|c|c|}
\hline RAVE & Social Support & $\begin{array}{c}\text { Work Family } \\
\text { Enrichment }\end{array}$ & OCB \\
\hline Social Support & 0.722 & & \\
\hline $\begin{array}{c}\text { Work Family } \\
\text { Enrichment }\end{array}$ & 0.446 & 0.779 & \\
\hline OCB & 0.294 & 0.442 & 0.716 \\
\hline
\end{tabular}

Sumber: Pengolahan data dengan Smart PLS 3 struk tertentu dengan indikatornya lebih tinggi dibandingkan dengan konstruk lainnya. Untuk menguji dari AVE dengan korelasi antar-variabel di mana nilai akar kuadrat dari AVE harus lebih besar daripada nilai korelasi antar-variabel laten (Ghozali, 2006:27).

Tabel tersebut menunjukkan bahwa variabel social support, work family enrichment, dan OCB pada penelitian ini memiliki nilai root average variance extracted (RAVE) berada di atas nilai korelasi dengan variabel lain. Hal ini menunjukkan bahwa indikator pertanyaan masing-masing variabel laten hanya dapat mengukur variabel yang diteliti tidak mengukur variabel yang lainnya.

Kemudian dilakukan evaluasi terhadap construct validity. Construct validity dilakukan untuk memastikan bahwa keseluruhan indikator valid dalam mengukur konstruk teori yang digunakan pada penelitian. Konstruk dikatakan memiliki construct validity yang baik jika nilai average variance extracted (AVE) berada di atas 0,5 (Ghozali, 2006). Berikut hasil pengujian construct validity penelitian.

Tabel Nilai Average Variance Extracted

\begin{tabular}{|l|c|c|}
\hline \multicolumn{1}{|c|}{ Variabel Construct } & (AVE) & Interpretasi \\
\hline Social Support & $\mathbf{0 . 5 2 1}$ & Valid \\
\hline Work Family Enrichment & $\mathbf{0 . 6 0 6}$ & Valid \\
\hline OCB & $\mathbf{0 . 5 1 2}$ & Valid \\
\hline
\end{tabular}

Tabel tersebut menunjukkan bahwa variabel social support dan work family enrichment pada penelitian ini memiliki construct validity yang tinggi karena nilai average variance extracted (AVE) berada di atas 0,5. Dengan demikian, semua pengujian validitas variabel-variabel pada penelitian menyatakan bahwa variabel pada penelitian ini memiliki indikator yang valid dalam mengukur masing-masing variabel yang diukur. 


\section{Uji Reliabilitas Model Pengukuran}

Pada penelitian ini, model pengukuran menghasilkan loading factor yang sudah melalui estimasi yang terstandardisasi (standardized estimate) dan akan dihitung nilai composite reliability-nya dan Cronbach's alpha. Berikut penyajian hasil uji reliabilitasnya.

Hasil Uji Reliabilitas Variabel Penelitian

\begin{tabular}{|l|c|c|c|}
\hline \multicolumn{1}{|c|}{ Variabel Construct } & Cronbach's & Composite & Interpretasi \\
\hline Social Support & 0.933 & 0.941 & Reliable \\
\hline Work Family Enrichment & 0.948 & 0.956 & Reliable \\
\hline OCB & 0.934 & 0.042 & Reliable \\
\hline
\end{tabular}

Sumber: lampiran output measurement model Smart PLS 3

Pada tabel uji reliabilitas, semua variabel penelitian menunjukkan nilai composite reliability $(\mathrm{pc})>0.6$ dan cronbach's alpha $>0.6$. Menurut Ghozali (2006), indikator pertanyaan dinyatakan reliabel jika nilai composite reliability $(\mathrm{pc})>0.6$ dan cronbach's alpha $>0.6$. Dengan demikian dapat disimpulkan bahwa itemitem pertanyaan pada semua variabel penelitian memiliki konsistensi dalam mengukur masingmasing variabel dalam waktu dan tempat yang berbeda. Dengan kata lain, semua variabel penelitian dapat dikatakan reliable dan dapat digunakan dalam model penelitian.

\section{Analisis Model Struktural}

Dalam penelitian ini, peneliti menggunakan metode structural equation modeling - partial least square. Analisis PLS akan menghasilkan model yang menggambarkan hubungan antar-variabel yang ada di dalamnya. Model struktural tersebut dikatakan baik dan dapat digunakan dalam penelitian jika memenuhi beberapa kriteria.

\section{Koefisien Determinasi}

Dalam menilai koefisien determinasi menggunakan nilai $R$-Square untuk setiap variabel laten endogen. Nilai $R$-Square dapat digunakan untuk menilai kemampuan variabel laten eksogen tertentu dapat menjelaskan terhadap variabel laten endogen. Tabel berikut merupakan hasil estimasi $R$-Square.

Tabel Nilai $R-S q u a r e$

\begin{tabular}{|l|c|}
\hline \multicolumn{1}{|c|}{ Variabel } & R Square \\
\hline Work Family Enrichment & 0.086 \\
\hline$O C B$ & 0.196 \\
\hline
\end{tabular}

Sumber: Pengolahan data dengan Smart PLS 3 |

Tabel tersebut menunjukkan nilai $R$-Square untuk variabel work family enrichment diperoleh sebesar 0,086. Hal ini menunjukkan bahwa 8.6\% variasi nilai dari work family enrichment mampu dijelaskan oleh variabel social support, sedangkan 91.4\% lainnya dijelaskan oleh variabel di luar model analisis. Nilai R-Square untuk variabel OCB diperoleh sebesar 0,196. Hal ini menunjukkan bahwa 19,6\% variasi nilai dari OCB mampu dijelaskan oleh variabel work family enrichment, sedangkan 80,4\% lainnya dijelaskan oleh variabel di luar model analisis.

Menurut Ghozali dan Latan (2012) penentuan kategori koefisien determinasi adalah sebagai berikut.

Tabel Penentuan Kategori Koefisien Determinasi

\begin{tabular}{|l|l|}
\hline Interval & Keterangan \\
\hline $0,34-1,00$ & Tinggi \\
\hline $0,20-0,33$ & Moderat \\
\hline $0,00-0,19$ & Rendah \\
\hline
\end{tabular}

Sumber: Ghozali dan Latan (2012) 
Arithea Ayu Amritha W. \& Ahmad Rizki Sridadi, Pengaruh Social Support terhadap Organizational Citizenship Behavior pada Karyawan Wanita di PT Inka dengan Work Family Enrichment sebagai Variabel Mediasi

Mengacu pada tabel tersebut dapat disimpulkan bahwa koefisien determinasi untuk variabel OCB termasuk dalam kategori moderat dikarenakan nilai R-square-nya berada di atas 1,9. Untuk variabel work family enrichment termasuk dalam kategori rendah dikarenakan nilai Rsquare-nya berada di bawah 1,9. Dengan demikian, dapat dikatakan bahwa model penelitian ini cukup baik dan dapat digunakan.

\section{PENGUJIAN HIPOTESIS}

Setelah mengetahui validitas dan reliabilitas item kuesioner dan mengetahui model yang dihasilkan dari analisis PLS dan kelayakan model. Peneliti akan melakukan pengujian hipotesis yang telah disusun sebelumnya. Pengujian hipotesis ini didasarkan pada nilai signifikansi $<0,05$ pada Path Coefficient. Jika nilai signifikansi kurang dari 0,05 maka terdapat pengaruh antarvariabel dan hipotesis diterima. Hasil uji hipotesis dapat dilihat pada tabel berikut.

\section{Hasil Uji Hipotesis Berdasarkan Path Coefficient}

\begin{tabular}{|l|c|c|c|c|}
\hline Pengaruh Antar Variabel & Path & T & P & Interpretasi \\
Coefficient & Statistic & & Signifikan \\
\hline $\begin{array}{l}\text { Social } \\
\text { Support } \rightarrow \quad \begin{array}{l}\text { Family } \\
\text { Enrichment }\end{array}\end{array}$ & 0.294 & 2.200 & 0.028 & Signifikan \\
\hline $\begin{array}{l}\text { Work } \\
\text { Family } \\
\text { Enrichment }\end{array}$ & 0.442 & 3.041 & 0.002 & OCB \\
Sumber : Output Structural Model Smart PLS 3
\end{tabular}

Pada tabel tersebut diketahui bahwa hasil uji hipotesis memiliki hipotesis 9 dan semua hipotesis dapat diterima. Hipotesis ini diterima dikarenakan nilai signifikansi (P) lebih kecil dari 0,05. Kemudian, T statistik $>1,96$ atau $<-1,96$. Penjelasan lebih lanjut tentang uji hipotesis adalah sebagai berikut.
Hipotesis 1: social support memiliki pengaruh yang signifikan terhadap work family enrichment

Hasil Parameter pengaruh variabel Social Support terhadap work family enrichment menunjukkan hasil yang signifikan dengan nilai signifikansi $0.028(\mathrm{p}<0,05)$ dan nilai $\mathrm{T}$ statistic $>1,96$ sebesar 2.200. Adapun pengaruh social support terhadap work family enrichment berpengaruh positif dengan nilai path coefficient weight sebesar 0.294. Berdasarkan hal tersebut maka dapat disimpulkan bahwa hipotesis yang menyatakan bahwa social support memiliki pengaruh yang signifikan terhadap work family enrichment dapat diterima.

Hipotesis 2: work family enrichment memiliki pengaruh yang signifikan terhadap OCB

Hasil Parameter pengaruh variabel work family enrichment terhadap OCB menunjukkan hasil yang signifikan dengan nilai signifikansi $0.002(\mathrm{p}<0,05)$ dan nilai $\mathrm{T}$ statistic $<1,96$ sebesar 3.041. Adapun pengaruh work family enrichment terhadap OCB berpengaruh positif dengan nilai path coefficient weight sebesar 0.442. Berdasarkan hal tersebut maka dapat disimpulkan bahwa hipotesis yang menyatakan bahwa work family enrichment memiliki pengaruh yang signifikan terhadap OCB dapat diterima.

Hipotesis 3: work family enrichment dapat memediasi hubungan antara social support dengan OCB

Berdasarkan hasil uji Sobel, peneliti dapat mengetahui variabel intervening dapat memediasi variabel independen terhadap variabel dependen. Nilai mutlak Z-value dari Z1 lebih besar dari 1.96 dengan nilai sebesar [2.240544], maka variabel Z1 dapat memediasi pengaruh X terhadap Y (Preacher and Hayes., 2004). Adapun besar 
pengaruh tidak langsungnya adalah 0.129948 . Dengan demikian, dapat diketahui bahwa hipotesis yang menyatakan bahwa work family enrichment dapat memediasi pengaruh social support terhadap OCB dapat diterima.

\section{PEMBAHASAN}

\section{Pengaruh Social Support Terhadap Work Fami- ly Enrichment}

Berdasarkan hasil penelitian, social support dapat berpengaruh signifikan positif terhadap work family enrichment. Hal ini menunjukkan dukungan yang baik dari lingkungan sosial karyawan di tempat kerja memengaruhi persepsi karyawan pada peran pekerjaan yang dilakukannya dalam meningkatkan kualitas dirinya menjalankan peran sebagai anggota keluarga. Semakin baik dukungan dari lingkungan sosial seperti manajemen perusahaan, supervisor langsung, dan rekan kerja akan menyebabkan karyawan merasa pekerjaan yang dilakukannya memberikan pengembangan pada dirinya, kualitas afeksi yang baik yang dapat membantu karyawan memenuhi kewajiban sebagai anggota keluarga sehingga work family enrichment karyawan semakin tinggi. Hal ini dikarenakan dukungan yang baik dari lingkungan sosial karyawan dapat memberikan kepercayaan diri dan mengurangi beban kerja karyawan sehingga karyawan memiliki energi yang cukup dan kualitas afeksi yang baik untuk menjalankan peran sebagai anggota keluarga. Dengan kata lain, karyawan PT Inka yang merasa mendapatkan dukungan dari lingkungan sosialnya akan mengalami work family enrichment. Hal tersebut selaras dengan konsep conservative of resources theory yang menjelaskan tingkah laku individu ditujukan untuk memperoleh, menggunakan, mempertahankan dan melindungi sumber daya (Hobfoll, 2002). Social sup- port menjadi salah satu sumber daya penting dalam lingkungan sosial yang dapat digunakan individu untuk menghadapi kondisi stress dalam hidup termasuk bagi individu yang menjalankan peran ganda sebagai karyawan dan anggota keluarga (Nicklin dan McNall, 2013). Karyawan yang menilai perusahaannya peduli pada kesejahteraannya akan merasa kebutuhan emosionalnya terpenuhi saat menjalankan peran kerjanya, perasaan terpenuhi tersebut akan menyediakan pengalaman psikologis yang baik, dan akan terbawa saat karyawan menjalankan peran sebagai anggota keluarga (McNall et al., 2011). Supervisor yang menjadi atasan langsung karyawan dapat mengurangi beban kerja dan tingkat stress yang dialami karyawan (Becker et al., 2005). Hal tersebut dapat memberikan energi dan kepercayaan diri yang tinggi kepada karyawan untuk memenuhi tanggung jawab sebagai anggota keluarga (Baral dan Bhargava, 2009). Selain itu, Carlson et al. (2011) berpendapat bahwa supervisor yang suportif mendorong karyawan untuk menggunakan kebijakan dan benefit yang disediakan organisasi untuk mencapai work family enrichment. Thompson dan Prottas (2006) juga berpendapat bahwa dukungan rekan kerja yang dapat membantu karyawan memenuhi tuntutan kerja dan permasalahan keluarga dapat mengurangi beban kerja yang dihadapi karyawan dan meningkatkan pengalaman psikologis saat bekerja sehingga hal tersebut dapat membantu karyawan menjalankan peran sebagai anggota keluarga dengan baik.

Hasil penelitian ini didukung oleh hasil penelitian Tang et al. (2012) yang menemukan bahwa social support pada dunia kerja yang berasal dari organisasi, supervisor, dan rekan kerja dapat meningkatkan work family enrichment karyawan yang memiliki peran ganda. Selain itu, Lu et al. (2009) juga menemukan 
Arithea Ayu Amritha W. \& Ahmad Rizki Sridadi, Pengaruh Social Support terhadap Organizational Citizenship Behavior pada Karyawan Wanita di PT Inka dengan Work Family Enrichment sebagai Variabel Mediasi

bahwa social support dapat berpengaruh signifikan positif terhadap work family enrichment. Siu et al. (2010) juga menemukan dukungan emosional dan instrumental yang kuat dari lingkungan sosial dapat meningkatkan work family enrichment karyawan.

\section{Pengaruh Work Family Enrichment Terhadap OCB}

Berdasarkan hasil penelitian, work family enrichment dapat berpengaruh signifikan positif terhadap OCB. Hal ini menunjukkan persepsi karyawan pada peran pekerjaan yang dilakukannya dalam meningkatkan kualitas dirinya menjalankan peran sebagai anggota keluarga dapat memengaruhi tindakan karyawan untuk melakukan OCB. Semakin baik kualitas diri karyawan dalam menjalankan peran sebagai anggota keluarga dikarenakan telah bekerja pada perusahaan menyebabkan karyawan melakukan aktivitas di luar job description pekerjaan yang seharusnya dilakukannya untuk menolong rekan kerja atau perusahaan secara keseluruhan sehingga OCB karyawan semakin tinggi. Hal ini dikarenakan karyawan yang merasa pekerjaannya membuat kualitas diri lebih baik saat menjalankan peran sebagai anggota keluarga akan merasa memiliki kewajiban untuk membalas kebaikan perusahaan dan lingkungan sosial di sekitar mereka. Dengan kata lain, karyawan PT Inka yang merasa mengalami work family enrichment akan mendorong karyawan melakukan OCB.

Hal tersebut selaras dengan konsep social exchange theory di mana karyawan yang merasa mendapatkan kebaikan dari organisasi dan lingkungan sosialnya akan merasa memiliki kewajiban untuk membalas kebaikan mereka dengan melakukan OCB (Lambert, 2000). Balmforth dan Gardner (2006) juga berpendapat bahwa karyawan yang telah mencapai work family enrichment akan merasakan kepuasan dan kesenangan sehingga akan berusaha melakukan tindakan timbal balik kepada organisasi dengan melakukan OCB. Greenhause dan Powell (2006) berpendapat bahwa work family enrichment mendorong seseorang untuk berkewajiban untuk melakukan tindakan yang terbaik untuk perusahaan termasuk OCB. Dengan demikian, pengaruh work family enrichment terhadap OCB karyawan PT Inka dilandasi dengan konsep social exchange theory di mana karyawan PT Inka merasa berterima kasih atas work family enrichment yang dialami dan berkeinginan untuk membalas kebaikan tersebut dengan melakukan OCB.

Hasil penelitian ini juga didukung oleh hasil penelitian Bragger et al. (2005) menemukan bahwa karyawan yang merasa tidak mampu memenuhi tanggung jawabnya sebagai anggota keluarga karena tuntutan pekerjaan, memiliki tingkat OCB yang rendah. Fenomena interaksi antara work family enrichment dengan OCB ini relatif kurang dieksplorasi dalam konteks negara berkembang. Hasil penelitian Baral dan Bhargava (2010) juga menemukan bahwa work family enrichment dapat berpengaruh positif signifikan pada OCB yang dilakukan oleh karyawan.

\section{Pengaruh Work Family Enrichment dalam Me-} mediasi Pengaruh Social Support Terhadap OCB

Berdasarkan hasil penelitian uji Sobel, work family enrichment dapat memediasi pengaruh social support terhadap OCB. Hal ini menunjukkan dukungan yang baik dari lingkungan sosial karyawan di tempat kerja dapat mendorong karyawan melakukan OCB dengan membuat karyawan beranggapan bahwa pekerjaan yang dilakukannya dapat meningkatkan kualitas dirinya menjalankan peran sebagai anggota keluarga. Semakin baik dukungan dari lingkungan sosial 
seperti manajemen perusahaan, supervisor langsung, dan rekan kerja akan mendorong karyawan melakukan OCB dikarenakan karyawan merasa pekerjaannya dapat meningkatkan kualitas diri lebih baik dalam menjalankan peran sebagai anggota keluarga. Hal ini disebabkan karyawan yang mendapat dukungan yang baik dari lingkungan sosial karyawan dapat membuat karyawan memiliki energi yang cukup dan kualitas afeksi yang baik untuk menjalankan peran sebagai anggota keluarga sehingga karyawan merasa berkewajiban untuk membalas kebaikan dengan melakukan OCB. Dengan kata lain, karyawan PT Inka yang mendapat social support akan mendorong karyawan melakukan OCB dengan mengalami work family enrichment terlebih dahulu.

Hasil penelitian ini selaras dengan konsep affective event theory (AET) di mana lingkungan sosial karyawan dalam tempat kerja yakni organisasi, supervisor, dan rekan kerja menjadi arsitek yang membentuk perasaan karyawan melalui pemberian feedback atas performa karyawan dan pemberian tugas atau arahan kepada karyawan (Dasborough dan Ashkanasy, 2003). Perasaan yang positif saat bekerja dapat membuat karyawan merasa tidak tertekan dalam menjalankan peran sebagai anggota keluarga sehingga mampu untuk melakukan OCB dengan sukarela (Chen dan Chiu, 2008). Selain itu, dukungan dari supervisor yang kuat dapat meningkatkan afeksi karyawan sehingga karyawan merasa puas pada hasil pekerjaannya dan membuat karyawan lebih mudah memenuhi tanggung jawabnya sebagai anggota keluarga sehingga karyawan merasa berkewajiban untuk membalas kebaikan yang diberikan perusahaan dengan melakukan OCB (Bragger et al., 2005). Hasil penelitian ini didukung oleh hasil penelitian Baral dan Bhargava (2010) yang menunjukkan bahwa work life enrichment mampu memediasi penuh hubungan antara social support dengan OCB yang dilakukan karyawan.

\section{SIMPULAN DAN SARAN}

Berdasarkan rumusan masalah, hipotesis, hasil, dan pembahasan maka simpulan penelitian ini adalah sebagai berikut.

1. Social Support memiliki pengaruh yang signifikan terhadap work family enrichment.

2. Work family enrichment memiliki pengaruh yang signifikan terhadap organizational citizenship behavior.

3. Work family enrichment dapat memediasi pengaruh social support terhadap organizational citizenship behavior.

\section{Saran bagi PT Inka}

Berdasarkan hasil penelitian menunjukkan bahwa OCB dipengaruhi secara signifikan oleh work family enrichment dan work family enrichment terbukti secara signifikan dipengaruhi oleh social support. Work family enrichment juga terbukti secara signifikan dapat memediasi pengaruh social support terhadap OCB. Adapun saran yang diberikan kepada manager PT Inka adalah sebagai berikut.

1. Melakukan dukungan organisasi yang lebih kuat pada karyawan untuk memenuhi kebutuhan keluarga seperti mengurangi tuntutan kerja yang berlebihan agar dapat memberikan waktu yang lebih banyak bersama keluarga, memberikan pelatihan keterampilan manajemen waktu agar dapat digunakan juga saat menjalankan peran sebagai anggota keluarga.

2. Memberikan pelatihan kepada supervisor untuk lebih peduli dan konsentrasi pada kebutuhan pribadi karyawan terkait keluarga. Hal tersebut diharapkan dapat mengurangi beban kerja karyawan sehingga masih memiliki ener- 
Arithea Ayu Amritha W. \& Ahmad Rizki Sridadi, Pengaruh Social Support terhadap Organizational Citizenship Behavior pada Karyawan Wanita di PT Inka dengan Work Family Enrichment sebagai Variabel Mediasi

gi yang cukup untuk menjalankan peran sebagai anggota keluarga.

3. Memberikan pelatihan dan event khusus yang mengedukasi karyawan untuk saling mendukung satu sama lain. Hal tersebut diharapkan dapat mengurangi beban kerja masing-masing karyawan jika sesama karyawan saling membantu satu sama lain sehingga karyawan.

\section{Saran bagi Akademisi}

Hasil Penelitian ini telah membuktikan model work family enrichment terbukti dapat memediasi pengaruh social support terhadap OCB dengan berdasarkan pada konsep social exchange theory dan affective event theory. Selain itu, akademisi diharapkan memanfaatkan model ini untuk mendapatkan pemahaman lebih dalam tentang work family enrichment sebagai manfaat dari karyawan yang menjalankan dua peran yakni sebagai karyawan dan anggota keluarga serta manfaat social support dari manajemen, supervisor, dan rekan kerja.

\section{RUJUKAN}

Aycan, Z. dan Eskin, M. 2005. "Relative Contributions of Childcare, Spousal Support, and Organizational Support in Reducing Work-Family Conflict for Men and Women: The Case of Turkey". Sex Roles, Vol. 53, Pp. 453-471.

Badan Pusat Statistik. 2018. Persentase Tenaga Kerja Formal Menurut Jenis Kelamin, 2015-2018. https:/www.bps.go.id/dynamictable/2018/05/16\%2000:00:00/1313/ persentase-tenaga-kerja-formal-menurutjenis-kelamin-2015-2018.html. Diakses 20 Juli 2019.

Barnett, R.C., \& Hyde, J.S. 2001. “Women, Men, Work, and Family: An Expansionist
Theory”. American Psychologist, Vol. 56 (10), pp. 781-796.

Becker, J.A.H., Halbesleben, J.R.B., \& O'Hair, H.D. 2005. Defensive Communication and Burnout in the Workplace: The Mediating Role of Leader-Member Exchange. Journal of Communication Research Reports. Vol. 22, No. 3, 143-150.

Beutell, N.J. \& Wittig-Berman, U. 2008. WorkFamily Conflict and Work Family Synergy for Generation X, Baby Boomers, and Matures: Generational Differences, Predictors, and Satisfaction Outcomes. Journal of Managerial Psychology, Vol. 23, No. 5, 507-523.

Bhate, Rucha. 2013. Supervisor Supportiveness: Global Perspectives. Quick Insights 3. Sloan Center on Aging \& Work at Boston College.

Bragger, J.D., Rodriguez-Srednicki, O., Kutcer, E.J., Indovino, L., \& Rosner, E. 2005. Work Family Conflict, Work Family Culture, and Organizational Citizenship Behavior Among Teachers. Journal of Business and Psychology, 20, 303-324.

Carlson, N.R. 2011. Psychology of Behavior. Boston: Allyn \& Bacon Paramount Publishing.

Chen, C.C. \& Chiu, S.F. 2009. The Mediating Role of Job Involvement in the Relationship between Job Characteristics and Organizational Citizenship Behavior. The Journal of Social Psychology. 149 (4), 474494.

Chen, Hsin-Chih. 2003. Cross Cultural Construct Validation of the Learning Transfer System Inventory in Taiwan. Dissertation. Louisiana State University.

Dasborough, M.T. \& Ashkanasy, N.M. 2002. Emotion and Attribution of Intentionality 
in Leader-Member Relationships. Leadership Quarterly, 13, 615"634.

Eddleston, K.A. \& Powell, G.N. 2012. Nurturing Entrepreneurs' Work-Family Balance: A Gendered Perspective. Entrepreneurship Theory \& Practice, 36, 513-541.

Feinberg, Emily Greene. 2013. Cross-Cultural Competence Training Effectiveness: The Impact of Training Transfer and Predictors of Transfer. Dissertation. University of Maryland, College Park.

Guest, D.E. 2002. Perspective on the Study of Work Life Balance. Social Science Information, 41:255.

Greenhaus, J.H. \& Powell, G.N. 2006. When Work and Family are Allies: A Theory of Work-Family Enrichment. Academy of Management Review, 31, 72-92.

Greenhaus, J.H. \& Powell, G.N. 2012. The Family-Relatedness of Work Decisions: A Framework and Agenda for Theory and Research. Journal of Vocational Behavior, 80, 246-255.

Hammer, L.B., Kossek, E.E., Zimmerman, K., \& Daniels, R. 2007. Clarifying the Construct of Family Supportive Supervisory Behaviors (FSSB). A Multilevel Perspective. Research in Occupational Stress and Well Being, 165-204.

Hammer, L.B., Kossek, E.E., Yragui, N.L., Bodner, T.E., \& Hanson, G.C. 2009. Development and Validation of a Multidimensional Measure of Family Supportive Supervisor Behaviors (FSSB). Journal of Management, 35(4), 837-856.

Hobfoll, S.E. 2002. Social and Psychological Resources and Adaptations. Review of General Psychology, 6, 302-324.

Jung, J.Y. and Hong, S. 2008. Organizational Citizenship Behaviour (OCB), TQM and
Performance at the Maquiladora. International Journal of Quality of Reliability Management, 25(8): 793-808.

Lambert, S.J. 2000. Added Benefits: The Link between Work-Life Benefits and Organizational Citizenship Behavior. Academy of Management Journal.

Marais, E., Klerk, M., Nel J.A., \& Beer. 2014. The Antecedents and Outcomes of Work Family Enrichment amongst Female Worker. SA Journal of Industrial Psychology, Vol. 40 (1), pp 1-14.

Michel, J.S., Mitchelson, J.K., Pichler, S., \& Cullen, K.L. 2010. Clarifying Relationships among Work and Family Social Support, Stressors, and Work Family Conflict. Journal of Vocational Behavior, 76, 91-104.

Mishra, P., Gupta R., \& Bhatnagar J., 2013. Exploring Work-Family Enrichment in an Emerging Economy. Qualitative Research Journal, Vol. 14, Iss 3, pp. 289-306.

Nicklin, J.M. \& McNall L.A. 2013. WorkFamily Enrichment, Support, and Satisfaction: A Test of Mediation Exploring Work-Family Enrichment in an Emerging Economy. European Journal of Work and Organizational Psychology.

Nijman, Derk-Jan J.M. 2004. Supporting Transfer of Training Effects of the Supervisor. University of Twente, Enschede.

Oren, Lior \& Levin, Liron. 2017. Work-Family Conflict/Enrichment: the Role of Personal Resources. International Journal of Manpower, Vol. 38, Issue 8.

Park, R. 2011. The Roles of OCB and Automation in the Relationship between Job Autonomy and Organizational Performance: A Moderated Mediation Model. The International Journal of Human Resource Management. 
Arithea Ayu Amritha W. \& Ahmad Rizki Sridadi, Pengaruh Social Support terhadap Organizational Citizenship Behavior pada Karyawan Wanita di PT Inka dengan Work Family Enrichment sebagai Variabel Mediasi

Podsakoff, P.M., et al. 2000. Organizational Citizenship Behavior: A Critical Review of the Theoretical and Empirical Literature and Suggestions for Future Research. Journal of Management, Vol. 26, No. 3.

Powell, G.N. 2011. Women and Men in Management (4th ed.). Los Angeles, CA: Sage. Shannock, Linda, Rhoades, \& Eisenberger Robeert, 2006. When Supervisor Feel Supported: Relationship with Subordinates' Perceived Supervisor Support, Perceived Organizational Support and Performance. Journal of Applied Psychology, Vol. 91, No. 3, 689-695.

Sieger, C.P. \& Wiese. B.S. 2009. Social Support from Work and Family Domains as an Antecedent or Moderator of Work Family Conflicts? Journal of Vocational Behavior. $75,26-37$.

Smith, C.A., Organ, D.W., \& Near, J.P. 1983. Organizational Citizenship Behaviour: It's Nature and Antecedent. Journal of Applied Psychology, Vol. 68 (4):653-663.

Soomro, A.A., Breitenecker, R.J., Shah, S.A.M. 2018. Relation of Work-Life Balance, Work-Family Conflict and Family-Work Conflict with the Employee PerformanceModerating Role of Job Satisfaction. South Asian Journal of Business Studies.

Susanto. 2010. Analysis of Effect of WorkFamily Conflict against Satisfaction Women Entrepreneurs Working in Semarang. Aset, 12: 175-85.
Stinglhamber, F., et al. 2006. Perceived Support as a Mediator of the Relationship between Justice and Trust. Group \& Organization Management, 31 (4), 442-468.

Talreja, Monika. 2017. Women Entrepreneurship and Work Life Balance. Global Journal of Human Social Science: H Interdisciplinary, Vol. 17, Issue 6.

Tang, S. \& Siu, O. 2012. A Study of WorkFamily Enrichment among Chinese Employees: The Mediating Role between Work Support and Job Satisfaction. Journal of Applied Psychology.

Twinarti, Ade. 2016. Hubungan antara Konflik Peran Ganda dengan Motivasi Kerja pada Wanita Karier. Skripsi Psikologi. Yogyakarta: Universitas Gadjah Mada.

Velada, Raquel António Caetano et al. 2007. The Effects of Training Design, Individual Characteristics, and Work Environment on Transfer of Training. International Journal of Training and Development, 11(4): 282-294.

Werner, Xuguang. 2016. Gender, Family and Business: An Empirical Study of Incorporated Self-Employed Individuals in the U.S. International Journal of Gender and Entrepreneurship, Vol. 8, Iss 4 pp.

Frone, M.R. 2003. "Work-Family Balance", in Quick, J.C. and Tetrick, L.E. (Eds). Handbook of Occupational Health Psychology, pp. 143-62. Washington DC: American Psychological Association. 
Accounting and Management Journal, Vol. 4, No. 1, July 2020 